\title{
PERLINDUNGAN HUKUM DARI KEKERASAN DALAM RUMAH TANGGA MENURUT UU NOMOR 23 TAHUN 2004
}

\author{
L Elly AM Pandiangan \\ elly.pandiangan@uki.ac.id \\ Universitas Kristen Indonesia, \\ Jakarta, Indonesia
}

\begin{abstract}
The Violence in Family often too difficult to detect and the public paradigm still assume that stuff is internal affairs of the families concerned, the presence of Laws number 23 years 2004 about the elimination of the violence at home, is expected to provide protection for the citizen of the state from the unconfortable sense and as forms of the violence however number of the violence at home in everyday instantly increase. As the Writer will explore how does the role of Laws number 23 years 2004 about exlusion of the violence at home in giving guarantee protections for the citizen of the state especially for them which is a victims of the violence that happened at home. By the question which focused on: Whether it has enough to protect the citizen of the state that being a victim of violence a Home?, and How should be done for decreasing of the number violence case at home that happened in Indonesia? The conclusion that founded by the writer that is principle Laws number 23 years 2004 about removal of the Violence at Home has been enough to provide the protection to the victims and the elementary to the law enforcement. But in its implementation must be done in a way of comprehence and sistematic, not only with the country through the tools of its power and also with the public that supporting the deletion of the violence at Home.
\end{abstract}

\section{Keywords: Perlindungan hukum dari kekerasan dalam rumah tangga}

\section{Pendahuluan}

Keluarga bagian terkecil dari masyarakat, dimana di dalam keluarga masing-masing anggotanya bertumbuhkembang secara sosial dan terjadinya pembentukan karakter diri seseorang, dipengaruhi terbesar dari keluarga. Anggota keluarga terdiri dari ayah, ibu, dan anak-anak., yang punya hubungan secara emosional dan sosial yang kuat dan saling mempengaruhi. Di dalam keluarga konflik atau perbedaan pendapat antara sesama anggota keluarga adalah hal yang wajar. Yang menjadi sorotan adalah bagaimana respon atas perbedaan pendapat yang mengarah kepada konflik internal keluarga tersebut: apakah diresponi dengan keterbukaan atas kritikan dan masukan, atau malahan direspon dengan kekerasan terhadap anggota keluarga yang berbeda pandangan atau yang berkonflik dengannya, Kekerasan dalam keluarga ini seringkali sulit dideteksi dan paradigma masyarakat masih menganggap hal iutu adalah urusan internal keluarga yang bersangkutan, masyarakat tidak etis mencampuri urusan rumah tangga orang lain.

${ }^{1}$ Dosen Tetap Fakultas Hukum Universitas Kriten Indonesia
Bagi hukum ranah keluarga adalah ranah privat yang tidak bisa sembarangan diterabas oleh hukum begitu saja. Hanya dalam aspek-aspek tertentu berkaitan keluarga, negara harus hadir untuk melindungi dan menjaga hak asasi manusia dari anggota-anggota keluarga. Kehadiran negara dalam memberikan jaminan perlindungan hukum dan hak asasi manusia dari anggota keluarga sangatlah penting. Dengan dilatarbelakangi paradigma masyarakat bahwa persoalan internal keluarga, termasuk adanya dugaan kekerasan, adalah bagian privat keluarga yang tidak boleh dicampuri oleh masyarakat umum. Maka peran negara hadir memmberikan prlindungan hukum dan hak asasi manusia melalui regulasi yang pro hak asasi manusia, khususnya bagi korban kekerasan dalam rumah tangga.

Indonesia telah membuat UU Nomor 23 Tahun 2004 tentang Penghapusan Kekerasan Dalam Rumah Tangga, hal mana merupakan kemajuan yang signifikan bagi negara dalam memberikan perlindungan dan jaminan hak asasi manusia bagi individu warga negaranya, khususnya sebagai anggota keluarga. 
Melalui UU Nomor 23 Tahun 2004 tentang Penghapusan Kekerasan Dalam Rumah Tangga, diharapkan memberikan perlindungan bagi warga negara dari rasa tidak aman dan bentuk-bentuk kekerasan yang tidak sesuai dengan nilai-nilai Pancasila dan Undang-Undang Dasar 1945. Sehingga warga negara terhindar atau dibebaskan dari kekerasan atau ancaman kekerasan, penyiksaan atau perlakuan yang merendahkan martabat dan derajat kemanusiaan, yang sangat mungkin sekali terjadi dalam keluarga (rumah tangga).

Berdasarkan data Komisi Nasional Hak Asasi Manusia Perempuan (Komnas HAM Perempuan) ${ }^{2}$ pada Tahun 2018 terdapat sebaganyak 348.446 kasus kekerasan terhadap perempuan yang dilaporkan dan ditangani oleh Komnas HAM Perempuan. Dari jumlah kasus sebanyak itu, kekerasan di ranah privat/personal tercatat paling tinggi mencapai $71 \%$ atau sekitar 9.609 kasus. Dari data ini sudah jelas bahwa di Indonesia kasus kekersasan dalam rumah tangga masih sangat tinggi meskipun sudah ada perlindungan yang diberikan oleh UU Nomor 23 Tahun 2004 tentang Penghapusan Kekerasan Dalam Rumah Tangga. Hal inilah yang penulis akan coba uraikan tentang bagaimana peranan UU Nomor

23 Tahun 2004 tentang Penghapusan Kekerasan Dalam Rumah Tangga dalam memberikan jaminan perlindungan bagi warga negara khususnya mereka yang telah menjadi korban kekerasan yang terjadi dalam rumah tangga. Apakah Perlindungan hak asasi manusia Di dalam UU RI No 23 tahun 2004 melindungi warga negara yang menjadi korban kekerasan dalam rumah tangga,Bagaimana mengurangi Tindak kekerasan dalam rumah tangga yang terjadi di Indonesia. Untuk mengetahui Perlindungan Hak asasi Manusia di dalam UU RI No 23 tahun 2004 tentang kekerasan di dalam rumah tangga. Untuk mengetahui cara-cara pengurangan tindak kekerasan di dalam rumah tangga.

\footnotetext{
${ }^{2}$ Komnas Perempuan, Lembar Fakta dan Poin Kunci Catatan Tahunan Komnas Perempuan Tahun 2018, 7 Maret 2018, disa- dur dari www.komnasperempuan.go.id/reads-lembar-fakta-dan- poinkunci-catatan-tahunan-catahu-komnas-perempuan-tahun- 2018 , diakses tanggal 7 Mei 2019, pukul 20.40 WIB
}

\section{Pembahasan}

\section{Fakta Kekerasan Dalam Rumah tangga}

Keberadaan UU Penghapusan Kekerasan Dalam Rumah Tangga sejak tahun 2004 memang dirasa belum dapat memberikan perlindungan dan jaminan bagi para korban kekerasan dalam rumah tangga. Bahkan di usianya yang memasuki tahun ke-5 di tahun 2019 ini, berdasarkan catatan dan penelitian dari Komnas Perempuan, kasus kekerasan terhadap perempuan, khususnya diranah privat/keluarga (kekerasan dalam rumah tangga) berjumlah $71 \%$ dari total kasus yang ditangani oleh Komnas Perempuan. Ini belum termasuk kasus-kasus yang belum terdata atau dilaporkan kepada Komnas Perempuan atau lembaga lainnya yang berkutat pada perlindungan perempuan dan anak. Meskipun saat ini sudah banyak korban yang memberanikan diri melaporkan tindakan kekerasan yang dialaminya dalam keluarga, tetapi masih mungkin lebih banyak lagi korban yang belum berani melaporkannya.

Berdasarkan ketentuan Pasal 1 angka 1 UU No. 23 tahun 2004 tentang Penghapusan Kekerasan Dalam Rumah Tangga, yang dimaksud dengan pengertian kekerasan dalam rumah tangga, yaitu: setiap perbuatan terhadap seseorang terutama perempuan, yang berakibat timbulnya kesengsaraan atau pen- deritaan secara fisik, seksual, psikologis, dan/atau penelantaran rumah tangga termasuk ancaman untuk melakukan perbuatan, pemaksaan atau perampasan kemerdekaan secara melawan hukum dalam lingkup rumah tangga.

Apabila dianalisis, pengertian kekerasan dalam rumah tangga berdasarkan rumusan UU Nomor 23 Tahun 2004 tersebut memang menekankan korbanya terkhusus adalah perempuan. Oleh karena umumnya secara fisik dan sosial, kedudukan perempuan lemah apabila dikaitkan dengan budaya patriarki yang mayoritas dianut oleh daerah-daerah di Indonesia. Perempuan umumnya menjadi korban kekerasan, ancaman kekerasan, seksual, psikologis dan lain sebagainya. Sebenarnya tidak hanya perempuan, anakanak pun punya kedudukan yang lemah dan rentan dalam keluarga. Dimana anak-anak berada dalam keadaan penguasaan orangtua dan sebagainya.

Perempuan dan anak menjadi korban berbagai bentuk kekerasan yang dialaminya. Menurut ketentuan Pasal 2 UU Nomor 23 Tahun 2004, yang menjadi lingkup undang-undang ini yaitu:

1. Suami, isteri, dan anak;

2. Orang-orang yang mempunyai hubungan keluarga dengan suami, istri dan anak, karena ada hubungan darah, perkawinan, persusuan, pengasuhan, dan perwalian, yang menetap dalam rumah tangga; dan/atau 
3. Orang yang bekerja membantu rumah tangga dan menetap dalam rumah tangga tersebut.

Jika dilihat dari lingkup subyek yang ditegaskan dalam ketentuan Pasal 2 UU Nomor 23 Tahun 2004 tersebut, maka cakupan perlindungan yang diberikan oleh undang-undang tersebut sangat luas. Rumah tangga tidak hanya berbicara anggota keluarga yang terdiri dari suami, istri dan anak, tetapi juga termasuk orang-orang yang mempunyai hubungan darah dengan keluarga inti (suami, istri, dan anak), juga mereka yang karena perkawinan, persusuan, pengasuhan dan perwalian, serta menetap tinggal dalam satu rumah tangga. Menariknya, karena luasnya lingkup perlindungan oleh UU Nomor 23 Tahun 2004 ini, bahkan sampai melindungi mereka yang berkerja sebagai asisten rumah tangga dan tinggal di rumah tangga tersebut. Artinya, dari segi perlindungan terhadap subyek menurut UU Nomor 23 Tahun 2004 ini sudah cukup mumpuni yang melindungi orangorang yang hidup dan menetap tinggal dalam satu rumah tangga. Dengan demikian perlindungan hak asasi manusia yang diberikan oleh UU Nomor 23 Tahun 2004 ini sudah sangat melindungi hak asasi manusia.

Apabila dilihat dari jenis atau bentuk kekerasan yang terjadi, maka UU Nomor 23 Tahun 2004 telah menegaskan bentuk-bentuk kekerasan yang dilarang, yang diatur dalam ketentuan Bab III mulai Pasal 5 sampai Pasal 9, yaitu:

1. Kekerasan fisik;

2. Kekerasan psikis;

3. Kekerasan seksual; atau

4. Penelantaran rumah tangga.

Kekerasan Fisik yang dimaksud disini adalah perbuatan yang mengakibatkan rasa sakit, jatuh sakit, atau luka berat. Contoh kekerasan dengan cara ini antara lain berupa: memukul, menampar, menendang, menarik rambut, menyundut dengan api rokok, melukai dengan senjata dan lain sebagainya. Kekerasan fisik ini diatur dalam ketentuan Pasal 6 UU Nomor 23 Tahun 2004. Selanjutnya yang dimaksud dengan kekesaran psikis menurut UU Nomor 23 Tahun 2004, yaitu perbuatan yang mengakibatkan ketakutan, hilangnya rasa percaya diri, hilangnya kemampuan untuk bertindak, rasa tidak berdaya, dan/ atau penderitaan psikis berat pada seseorang. Contoh kekerasan dengan cara ini dapat berupa antara lain: tindakan penghinaan, pendapat atau komentar yang merendahkan harga diri, mengisolir istri dari dunia luar, mengancam atau menakut-nakuti yang bertujuan untuk memaksakan kehendak si pelaku. Kekerasan psikis ini diatur dalam ketentuan Pasal 7 UU Nomor 23 Tahun 2004
Berikutnya pengertian Kekerasan seksual yang dimaksudkan dalam UU Nomor 23 Tahun 2004, yaitu meliputi:

1. pemaksaan hubungan seksual yang dilakukan terhadap orang yang menetap dalam lingkup rumah tangga tersebut; dan

2. Pemaksaan hubungan seksual terhadap salah seorang dalam lingkup rumah tangganya dengan orang lain untuk tujuan komersial dan/atau tujuan tertentu

Contoh bentuk kekerasan seksual antara lain berupa pemaksaan melakukan hubungan seksual, memaksakan selera seksual sendiri, menjauhkan istri dari kebutuhan batinnya, dan lain sebagainya. Bentuk kekerasan seksual ini diatur dalam ketentuan Pasal 8 UU Nomor 23 Tahun 2004. Bentuk yang terakhir yaitu berupa penelantaran rumah tangga. Pengertian penelantaran rumah tangga ini diatur dalam ketentuan Pasal 9 UU Nomor 23 Tahun 2004. Isi ketentuan menegaskan bahwa yang dilarang adalah perbuatan menelantarkan orang dalam lingkup rumah tangganya padahal menurut hukum yang berlaku baginya atau karena persetujuan atau perjanjian, ia wajib memberikan kehidupan, perawatan atau pemeliharaan kepada orang itu. Selain itu pada ketentuan Pasal 9 ayat (2) UU Nomor 23 Tahun 2004, ditegaskan bahwa penelantaran tersebut juga berlaku bagi setiap orang yang mengakibatkan ketergantungan ekonomi dengan cara membatasi dan/atau melarang untuk bekerja yang layak di dalam atau di luar rumah sehingga korban berada di bawah kendali orang tersebut. Contoh bentuk penelantaran ini bisa berupa tidak memberi nafkah terhadap istri dan bahkan sampai menghabiskan sendiri uang penghasilan dari istri.

Dari keempat bentuk kekerasan yang ditegaskan dalam UU Nomor 23 Tahun 2004 tersebut, artinya UU Nomor 23 Tahun 2004 memang secara limitatif sudah membatasi bentuk-bentuk kekerasan yang sangata terlarang menurut UU Nomor 23 Tahun 2004 ini. Dengan demikian, contoh perilaku atau kasus bentuk-bentuk kekerasan tersebut bisa lebih banyak variasinya dalam kasus, yang tinggal dimasukan ke dalam bentuk yang mana sebagaimana pengaturan menurut UU Nomor 23 Tahun 2004.

Menurut Strauss A Murray ${ }^{3}$, dominannya peran laki-laki dalam struktur masyarakat dan juga keluarga sehingga tidak tertutup kemungkinan bisa terjadi kekerasan dalam suatu rumah tangga, contohnya dalam hal berikut:

\footnotetext{
${ }^{3}$ Ferry Efendi dan Mahfudhi, Keperawatan Kesehatan Komunitas Teori dan Praktek Keperawatan, Jakarta: salemba Medika, 2009, h. $195-196$
} 
1. Adanya pembelaan kekuasaan laki-laki, yang dianggap sebagai superioritas sumber daya dibandingkan wanita, karena dianggap laki-laki mampu mengatur dan mengendalikan si wanita;

2. Adanya diskrimniasi dan pembatasan ekonomi, dimana wanita dibatasi kesempatan untuk bekerja sehingga istri sangat bergantung pada suami (lakilaki), dan apabila si laki-laki kehilangan pekerjaan maka istri mengalami tindakan kekerasan;

3. Adanya beban pengasuhan anak, dimana istri yang tidak bekerja menjadi penanggung beban sebagai pengasuh anak, sehingga suami akan menyalahkan istri apabila terjadi hal yang tidak diharapkan pada anak;

4. Adanya konsep wanita sebagai milik laki-laki (suami) menurut hukum, sehingga laki-laki memiliki keleluasaan untuk mengatur dan mengendalikan segala hak dan kewajiban wanita, termasuk merasa berhak untuk melakukan kekerasan terhadap anak supaya menjadi tertib;

5. Adanya orientasi pengadilan pidana pada laki-laki, disini posisi wanita sebagai istri yang mengalami kekerasan dalam rumah tangga akibat tindakan suaminya, dianggap sebagai pelanggaran terhadap hukum, dan penyelesaiannay sering ditunda atau ditutup, dengan alasan adanya legitimasi hukum bagi suami untuk melakukan kekerasan sepajang dalam konteks harmoni keluarga.

Berdasarkan Survei Pengalaman Hidup Perempuan Nasional (SPHN) Tahun 2016 yang dilakukan oleh Kementerian Pemberdayaan Perempuan dan Perlindungan $\mathrm{Anak}^{4}$, diperoleh beberapa alasan yang menjadi sebab terjadinya kekerasan dalam rumah tangga, yaitu:

1. Faktor Individu Perempuan

2. Faktor Pasangan

3. Faktor ekonomi

4. Faktor Sosial Budaya

\section{Faktor Individu Perempuan}

Hasil SPHN Kementerian Pemberdayaan Perempuan dan Perlindungan Anak Tahun 2016, didapati bahwa dilihat dari bentuk pengesahan perkawinan, seeperti kawin siri, secara agama, adat, kontrak atau bentuk lainnya. Disini perempuan berpotensi 1,42

\footnotetext{
${ }^{4}$ Kementerian Pemberdayaan Perempuan dan Perlindungan Anak, Perempuan rentan Jadi Korban KDRT, Kenali Faktor Penyebabnya, Jakarta, 2018, disadur dari www.kemenpppa.go.id/index. php/page/read/31/1742/perempuan-rentan-jadi-korban-kdrt-kenali-faktor-penyebabnya, diakses pada tanggal 7 Mei 2019, pu- kul 10.23 wib
}

kali memgalami kekerasan fisik dan/atau seksual dibandingkan dengan wanita yang menikah secara resmi diakui negara melalui Kantor Urusan Agama (KUA) atau Kantor Catatan Sipil. Selain itu, SPHN juga mendapati bahwa faktor sering bertengkar terusmenerus dengan suami, didapati bahwa wanita berpotensi 3,95 kali lebih tinggi mengalami kekerasan fisik dan/atau seksual dibandingkan dengan wanita yang jarang bertengkar dengan suami/pasangannya. Kemudian wanita yang sering menyerang suami/ pasangannya lebih dahulu, sangat berisiko 6 kali lebih besar akan mengalami kekerasan fisik dan atau seksual dibandingkan wanita yang tidak menyerang terlebih dahulu,

\section{Faktor Pasangan}

Untuk faktor ini, SPHN mendapati bahwa wanita yang suaminya memiliki pasangan lain maka memiliki risiko 1,34 kali lebih besar mengalamai kekerasan fisik dan/atau seksual dibandingkan wanita yang suaminya tidak memiliki pasangan lain. Demikian juga dengan wanita yang suaminya berselingkuh cenderung berpotensi2,48 kali lebih besar mengalami kekerasan fisik dan/atau seksual.

Faktor suami yang menganggur juga membuat wanita berisiko 1,36 kali lebih besar alami kekerasan fisik dan/atau seksual. Termasuk juga wanita yang memiliki suami yang pernah minum miras berisiko hingga 1,56 kali lebih besar akan mengalami kekersan fisik dan/atau seksual. Begitu juga dengan wanita yang bersuamikan pengguna narkotika berisiko 2 kali besar dibanding mereka yang suaminya tidak memakai narkotika.

Wanita yang memiliki suami pengguna narkotika didapati 45,1\% mengalami kekerasan fisik, kemudian sebanyak 35,6\% mengalami kekerasan seksual, selanjutnya $54,7 \%$ mengalami kekerasan fisik dan seksual, 59.3\% mengalami kekerasan ekonomi, $61.3 \%$ mengalami kekerasan psikis, dan $74.8 \%$ wanita mengalami kekerasan pembatasan aktivitas.

\section{Faktor Ekonomi}

Wanita yang berasal dari rumahtangga dengan kesejahteraan rendah cenderung berisiko tinggi alami kekerasan fisik dan/atau seksual yang dilakukan oleh pasangannya. Berdasarkan data SPHN 2016, 25\% wanita yang berasal dari rumah tangga termiskin berisiko 1,4 kali alami kekerasanfisik dan.atau seksual dari suaminya. Faktor ekonomi ini menjadi dominan dibandingkan aspek pendidikan, hal inidiindikasikan pada pekerjaan pelaku yang mayoritas adalah buruh. 


\section{Faktor Sosial Budaya}

Berdasarkan hasil SPHN, wanita yang tinggal di perkotaan berisiko 1,2 kali lebih besar mengalami kekerasan fisik dan/atau seksual dari pasangannya, serta timbulnya adanya rasa khawatir akan kejahatan yang mengancam juga mempengaruhi wanita yang dibayangi perasaaan ini akan berisiko 1,68\% lebih besar alami kekerasan fisik dan/atau seksual dibandingkan mereka yang tidak khawatir akan bahaya kejahatan.

\section{Kekerasan Dalam Rumah Tangga adalah Suatu Kejahatan}

Kekerasan dalam rumah tangga dalam berbagai variasi bentuknya adalah suatu kejahatan dan pelanggaran terhadap hak asasi manusia. Oleh karenanya UU Nomor 23 Tahun 2004 tentang Penghapusan Kekerasan Dalam Rumat tangga juga mengatur tentang sanksi pidana atas kekerdasan dalam rumah tangga ini.Dalam hukum pidana dikenal asas legalitas, yaitu asas yang menegaskan tiada pidana yang dijatuhkan apabila belum ada undang-undang yang mengaturnya. Artinya suatu perbuatan meskipun tercela menurut masyarkat, apabila belum ada undangundang yang menegaskan ancaman sanksi pidananya, maka perbuatan tersebut tidak bisa dipidana. Atau dikenal dengan ajaran Ansel von Feurbach ${ }^{5}$ yang memperkenalkan Nullum Delictum Nulla Poena Sine Praevia Lege Poenali yang mempengaruhi asas legalitas yang dianut Pasal ayat (1) KUHP di Indonesia. Ketentuan Pasal 1 ayat (1) KUHP ${ }^{6}$ ini berbunyi: "Tiada suatu perbuatan dapat dipidana, kecuali atas kekuatan aturan pidana dalam perundang-undangan yang telah ada, sebelum perbuatan dilakukan". Maksud dari ketentuan Pasal 1 ayat (1) KUHP tersebut, yaitu ketentuan pidana itu harus ada terlebih dahulu dari perbuatan itu, atau dengan perkataan lain bahwa ketentuan pidaa itu sudah berlaku ketika perbuatan itu dilaksanakan oleh pelaku. Jadi tidak ada berlaku surut dalam hukum pidana ${ }^{7}$.

Hal ini untuk menjamin kepastian hukum bagi pencari keadilan, dimana ada undang-undang tertulis yang menegaskan adanya perbuatan atau tindakan yang dapat dipidana tersebut (tindak pidana). Keberadaan UU Nomor 23 Tahun 2004 tentang Penghapusan Kekerasan Dalam Rumah Tangga sudah

\footnotetext{
${ }^{5}$ SR Sianturi, Asas-asas Hukum Pidana di Indonesia dan Penerapannya, Jakarta: Alumni Ahaem-Petehaem, 1996, h.73

${ }^{6}$ Moeljatno, Kitab Undang-Undang HUkum Pidana, Jakarta: Bumi Aksara, 1999, h.3

${ }^{7}$ D. Schaffmeister, dkk, Hukum Pidana, Bandung: CItra Aditya
}

sesuai dengan asas legalitas dalam hukum pidana, oleh karena pada Bab VIII pada ketentuan Pasal 44 sampai Pasal 53 diatur tentang sanksi pidan ayang diancamkan sehubungan dengan tindakan kekerasan dalam rumah tangga.

Ancaman Pidana yang diancamkan dalam ketentuan Pidana pada UU Nomor 23 Tahun 2004 tersebut, telah mengancamkan pidana pokok berupa: (1) pidana penjara dengan pengaturan strafminima 4 tahun dan strafmaxima 20 tahun penjara; dan

(2) pidana denda dengan pengaturan strafminima sebanyak Rp 3.000.000,00 (tiga juta rupiah) dan strafmaxima sebanyak Rp 500.000.000,00 (lima ratus juta rupiah); serta pidana Tambahan berupa pembatasan gerak pelaku untuk menjauhkan pelaku dari korban selam ajangka waktu tertentu dan jarak tertentu atau pembatasan hak-hak tertentu, dan mengikuti program konseling di lembaga tertentu.

Melihat sanksi pidana yang diancamkan dalam UU Nomor 23 Tahun 2004 ini, kita bisa melihat betapa seriusnya negara memberikan penghukuman bagi pelaku dilihat dari strafminima dan strafmaxima pidana pokok dan tambahan yang diancamkan. Meskipun ada beberapa tindak pidan ayang disyaratakan dengan adannya pengaduan dari korban (delik aduan /klacht delict). Dengan demikian, melihat dari segi regulasinya sebenarnya penghapusan kekerasan dalam rumah tangga sudah cukup mumpuni tinggal bagaiman pelaksanaan penegakkan hukum di lapangan, serta bagaimana mencegah atau setidaknya meminimalisir kasus kekerasan dalam rumah tangga yang terjadi di Indonesia.

Berdasarkan Catatan Kekerasan terhadap Perempuan tahun 2017 yang dibuat oleh Komnas Perempuan pada tanggal 7 Maret 2018 ${ }^{8}$, hasil riset Komnas Perempuan tersebut merumuskan aspek peranan negara sebagai berikut:

1. Efektivitas perlindungan hukum: KDRT masih sangat dominan menjadi isu kekerasan yang dikenalidandila;orkankarenaadanayperlindungan hukumnya. Penyelesaian KDRT cenderung diselesaikan dengan perceraian dibanding dengan memproses dimensi pidananya. Situasi inilah yang memicu impunitas. Namun penting membaca kedayagunaan dan implementasi UU PKDRT yang cenderung digunakan korban untuk melaporkan namun semakin kecil digunakan untuk melindungi perempuan dari kekerasan yang dihadapinya, teruama dengan banyaknya kriminalisasi perempuan korban KDRT karena aparat negara salah baca masalah. 
Berkaitan dengan itu Komnas Perempuan ${ }^{9}$ juga merekomendasikan Perlindungan Hukum dan Pemenuhan Hak Perempuan Korban, yaitu:

a) Kepolisian RI, Kejaksaan Agung RI dan Mahkamah Agung RI: membangun SOP pena- nganan kejahatan cyberdan pemulihan perempuan korban;

b) Kementerian Pemberdayaan Perempuan dan Perlindungan Anak memastikan UU PKDRT substansi dan mekanismenya dijalankan oleh semua pihak terutama perlindungan pada korban dan akses keadilan bagi korban serta penghukuman untuk mencegah impunitas;

c) Kementerian Dalam Negeri melakukan peng- awasan dan pembinaan atas penyelenggaraan good governance untuk melindungi perempuan dari kekerasan;

d) Kementerian Koordinator PMK melakukan sistem pencegahan dan penanganan isu-isu yang memicu konflik di masyarakat untuk memastikan hak keadilan dan pemulihan bagi warga negara;

e) Kementerian Perumahan Rakyat memberikan prioritas untuk perumahan, yang diprioritaskan kepada korban kekerasan terhadap perempuan termasuk single parents untuk mencegah dari jeratan sindikasi narkoba, sasaran trafiking maupun migrasi yang tidak terlindungi.

Menurut penulis apa yang direkomendasikan oleh Komnas Perempuan sudah tepat berupa upaya komprehensif dan sinergi antar kementerian, institusi dan lembaga untuk mencegah terjadinya kekerasan dalam rumah tangga, termasuk untuk penindakkan atas pelanggaran hukum khususnya pelanggaran terhadap UU Nomor 23 Tahun 2004 tentang Penghapusan Kekerasan Dalam Rumah Tangga.

\section{Kesimpulan dan Saran}

Keberadaan UU Nomor 23 Tahun 2004 tentang Penghapusan Kekersan Dalam Rumah Tangga secara substansial materi sudah cukup memberikan jaminan perlindungan bagi korban kekerasan dalam rumah tangga dan penegakkan hukum bagi pelaku kekerasan dalam rumah tangga. Tinggal di tataran implementasinya yang harus diterapkan secara komprehensif dan sinergi antar lembaga penegak hukum, yaitu kepolisian, Kejaksaan, Pengadilan, serta Advokat, Untuk dapat mengurangi terjadinya atau berulangnya tindakan-tindakan atau kasus-kasus kekerasan dalam rumah tangga diperlukan upaya sistematis dan komprehensif, baik dari Negara melalui lembaga dan alat-alat kekuasaannya, maupun dari masyarakat yang mendukung upaya penghapusan kekerasan dalam rumah tangga.

Perlu kerjasama diantara Penegak hukum dalam memberi penerangan kepada Masyarakat untuk mencegah kekersasan di dalam rumah tangga, Perlu dibangun kesadaran di masyarakat agar membina keluarga dalam menjalankan aktifitas sehari-hari

\footnotetext{
${ }^{9} \mathrm{Ibid}$, Komnas Perempuan, h. 98
} 


\section{Daftar Pustaka}

\section{Buku}

D Schaffmeister, dkk, Hukum Pidana, Bandung: CItra Aditya Bakti, 2007.

Ferry Efendi dan Mahfudhi, Keperawatan Kesehatan Komunitas Teori dan Praktek Keperawatan, Jakarta: Salemba Medika, 2009.

Moeljatno, Kitab Undang-Undang HUkum Pidana, Jakarta: Bumi Aksara, 1999.

SR Sianturi, Asas-asas Hukum Pidana di Indonesia dan Penerapannya, Jakarta: Alumni AhaemPetehaem, 1996.

\section{Undang-Undang}

Undang-Undang Republik Indonesia Nomor 23 Tahun 2004 Tentang Penghapusan Kekerasan Dalam Rumah Tangga, Lembaran Negara Tahun 2004 Nomor 95;

Undang-Undang Republik Indonesia Nomor 73 Tahun 1958 Tentang Menyatakan Berlakunya Undang-Undang Nomor 1 Tahun 1946 tentang Peraturan Hukum Pidana untuk Seluruh Wilayah Republik Indonesia dan Mengubah Kitab Undang-Undang Hukum Pidana, Lembaran Negara Tahun 1958 Nomor 127;

Internet:

Komnas Perempuan, Lembar Fakta dan Poin Kunci Catatan Tahunan Komnas Perempuan Tahun 2018, 7 Maret 2018, disadur dari www.komnasperempuan. go.id/reads-lembar-fakta-dan-poin-kunci-catatantahunan-catahu-komnas-perempuan-tahun-2018, diakses tanggal 7 Mei 2019, jam 20.40 WIB

Kementerian Pemberdayaan Perempuan dan Perlindungan Anak, Perempuan rentan Jadi Korban KDRT, Kenali Faktor Penyebabnya, Jakarta, 2018, disadur dari www.kemenpppa.go.id/index.php/page/ read/31/1742/perempuan-rentan-jadi-korban-kdrt- kenali-faktor-penyebabnya, diakses pada tanggal 7 Mei 2019, pukul 10.23 WIB 